\title{
First record of microplastics in two freshwater fish species (Iheringhthys labrosus and Astyanax lacustris) from the middle section of the Uruguay River, Brazil
}

Primeiro registro de microplástico em duas espécies de peixe

(Iheringhthys labrosus e Astyanax lacustris) num trecho do Médio Rio Uruguai, Brasil

Tacieli dos Santos $^{1}$ (D), Rodrigo Bastian ${ }^{1}$ (D), Juliana Felden ${ }^{1}$ (D), Adelita Maria Rauber ${ }^{1}$ (D), David Augusto Reynalte-Tataje ${ }^{1}$ (D) and Franco Teixeira de Mello ${ }^{2 *}$

${ }^{1}$ Universidade Federal da Fronteira Sul - UFFS, Address, Av. Jacob Reinaldo Haupenthal, 1580 Bairro São Pedro, 97900-000, Cerro Largo, RS, Brasil

${ }^{2}$ Departamento de Ecología y Gestión Ambiental, Centro Universitario Regional del Este - CURE, Universidad de la República - UdelaR, Tacuarembó entre Bvar. Artigas y Av. Aparicio Saravia CP 2000, Maldonado, Uruguay

*e-mail: frantei@cure.edu.uy

Cite as: Santos, T. et al. First record of microplastics in two freshwater fish species (Iheringhthys labrosus and Astyanax lacustris) from the middle section of the Uruguay River, Brazil. Acta Limnologica Brasiliensia, 2020, vol. 32, e26.

Abstract: Aim: The aim was to analyze the incidence of microplastics in the diet of fish in the middle Uruguay River. Methods: The present work analyzed the gastrointestinal content of two species: Astyanax lacustris and Iheringichthys labrosus. Results: This study provides the first evidence of synthetic materials, such as fibres and plastics in the gastrointestinal tract of fish species in the Middle Uruguay River basin. A sample of sixty-one A. lacustris and twenty-nine I. labrosus were examined to highlight the ingestion of microplastics in the middle section of the Uruguay River in Brazil. In the $A$. lacustris, eleven fibres and two fragments were found in their gastrointestinal contents, corresponding to $18.1 \%$ of the specimens, while in the I. labrosus, twelve fibres and one fragment were found, corresponding to $34.5 \%$ of the specimens analyzed. Blue staining was also prevalent in the occurrence of microplastics. Conclusions: These data are the first record of microplastics in this zone and represent a baseline for this contamination for future studies.

Keywords: environmental contamination; freshwater fishes; Uruguay River; microplastic ingestion.

Resumo: Objetivo: $\mathrm{O}$ objectivo foi analisar a incidência de microplásticos na dieta dos peixes no meio do Rio Uruguai. Métodos: O presente trabalho analisou o conteúdo gastrointestinal de duas espécies: Astyanax lacustris e Iheringichthys labrosus. Resultados: Uma amostra de sessenta e um indivíduos de $A$. lacustris e vinte e nove indivíduos de I. labrosus foi examinada para destacar a ingestáo de microplásticos na seção média do rio Uruguai no Brasil. Em A. lacustris, foram encontradas onze fibras e dois fragmentos em seu conteúdo gastrointestinal, correspondendo a $18,1 \%$ das amostras, enquanto no I. labrosus foram encontradas doze fibras e um fragmento, correspondentes a $34,5 \%$ das amostras analisadas. A coloração azul também foi prevalente na ocorrência de microplásticos. Conclusóes: Esses dados sáo o primeiro registro de microplásticos nessa zona e representam uma linha de base para essa contaminação para estudos futuros.

Keywords: contaminação ambiental; peixes de água doce; Rio Uruguai; ingestão microplástica. 
Global plastic production has increased exponentially since the 1950 s, from 5 million tonnes/year to 300 million tonnes/year in 2013 (Rochman et al., 2013). Research efforts have also increased, which show that this is a global problem with local implications for biodiversity. Microplastics (MPs, $<5 \mathrm{~mm}$ ) can be found around the world, even in remote areas such as the Antarctic (Lacerda et al., 2019).

In the last few years, different studies have identified MPs in rivers, lakes, and estuaries in Africa, Asia, Europe, and North America and in these studies the MPs are from primary and secondary sources (Eerkes-Medrano et al., 2015; Wu et al., 2020). MPs can have long residence times in freshwater systems as they are transported (Browne et al., 2011). As the number of MPs in freshwater systems and the residence times increase, the risk of exposure and interaction with fauna also increases. The aim of this work was to analyze the incidence of microplastics in the diet of fish in the middle Uruguay River. For this purpose, we selected two species that are representative of the Uruguay River with different trophic habits in five different sites.

The studied species Astyanax lacustris (Lutken, 1875 ) is a small an omnivorous fish, widely distributed throughout the basin, it inhabits the water column and also usually feeds on macroinvertebrates in the bottom sediments (Hartz et al., 1996). On the other hand, Iheringichthys labrosus (Lütken, 1874) is a midsize catfish species also widely distributed throughout the basin, living in the bottom of the river and feeds mainly on macroinvertebrates and also plant remains (Abes et al., 2001; Masdeu et al., 2011; Silva et al., 2019). These two omnivorous species play an important role in the trophic web because they represent the connection between macroinvertebrates and basal resources with the piscivorous fish (Abes et al., 2001; Gomiero \& Braga, 2003; Masdeu et al., 2011; D’Anatro et al., 2013). In addition to their flexible trophic habits, these species have great reproductive flexibility, both characteristics contribute to their widely distribution throughout the Uruguay River basin (Esteves, 1996; Andrian et al., 2001; D'Anatro et al., 2013; Silva et al., 2019; Vidal et al., 2020).

The Uruguay River course covers about $2,200 \mathrm{~km}^{2}$ in length which is divided into the upper, middle and lower Uruguay River. The species were collected from five sampling stations (RS, Brazil) in the middle section of the Uruguay river between February 2018 and
January 2019. Three of the stations were located in the main river channel in the municipalities

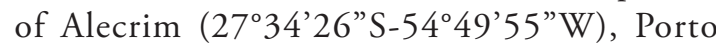

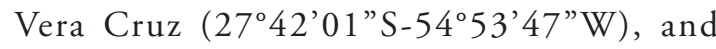
São Borja (28 34'15”S-56 09'51”W) and two were in the tributaries in the municipalities of São Paulo das Missóes (Comandaí river, $27^{\circ} 59^{\prime} 26^{\prime \prime S}-54^{\circ} 53^{\prime} 04^{\prime \prime W}$ ) and Roque Gonzales

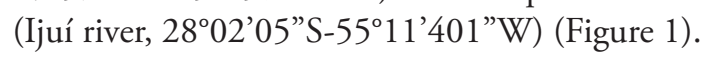

For this study, the individuals were collected with multi-mesh gill nets ( 15 to $25 \mathrm{~mm}$ knot to knot) and seine nets. Immediately after the fish were captured, the standard body length and total weight of all the individuals were measured and the gastrointestinal tract was removed and fixed in $10 \%$ formaldehyde. To separate MP from the digestive tract of fish, the methodology recommended by Rochman et al. (2015) and Woodall et al. (2015) was used. A direct light microscope (Nikon Eclipse 50i) equipped with a polarized light system was used to reduce the number of fibres that might not be synthetic material. We classified and selected as plastic the particles that showed some kind of birefringence behavior (Sierra et al., 2020), we only included the MPs that were at least $1 \mathrm{~mm}$ in size. During the microscopic analysis, using direct light, the characteristics of the MPs were noted such as: type (fibre or fragment, Figure 2), color and size $(\mathrm{mm})$.

Ninety gastrointestinal contents were analyzed, of which sixty-one belonged to $A$. lacustris and twenty-nine to I. labrosus. Of the total analyzed, $18.1 \%$ of $A$. lacustris and $34.5 \%$ of I. labrosus presented MPs in the gastrointestinal tract. A larger proportion of the I. labrosus species had MPs in their gastrointestinal tract in comparison with $A$. lacustris, this finding may be due to differences in the foraging feeding strategies of both species. The I. labrosus, unlike $A$. lacustris, feeds in the bottom sediments, so there could be a higher density of MPs in this environment. Also, the I. labrosus had the highest number of fibres in one individual (3 versus 2 ) and the maximum fibre size (10 $\mathrm{mm}$ versus $4 \mathrm{~mm})$ probably related to the larger size of the mouth when compared to A. lacustris (Figure 3).

In this study, the most frequent synthetic materials were fibres, representing $88.5 \%$. The predominant color was blue, $73.9 \%$ (white $17.5 \%$, red $4.3 \%$ and black 4.3\%), with an average size of $2.6 \pm 1.9 \mathrm{~mm}$. Both analyzed species presented MPs in all the stations that were studied (Table 1).

Ingestion of synthetic material can occur directly in the water column or indirectly when 


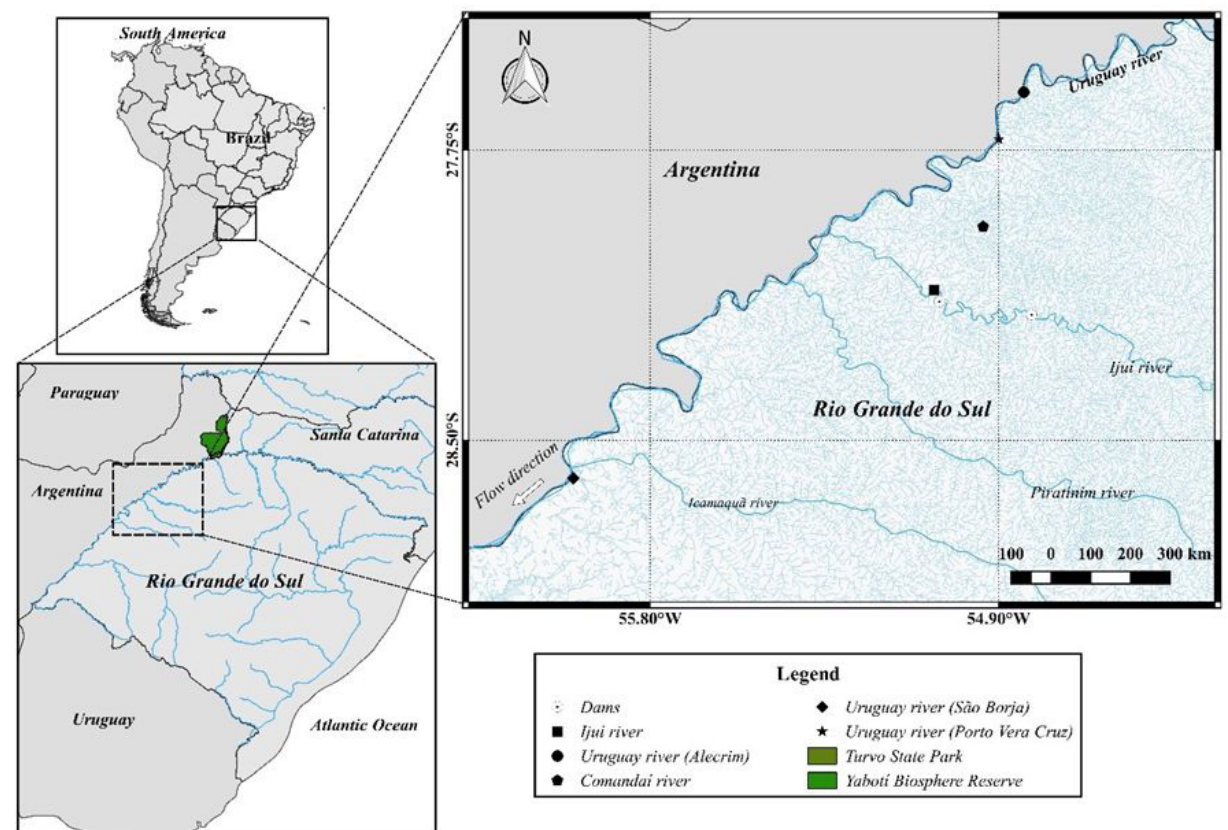

Figure 1. Study area, the location of the sampled sites can be observed.

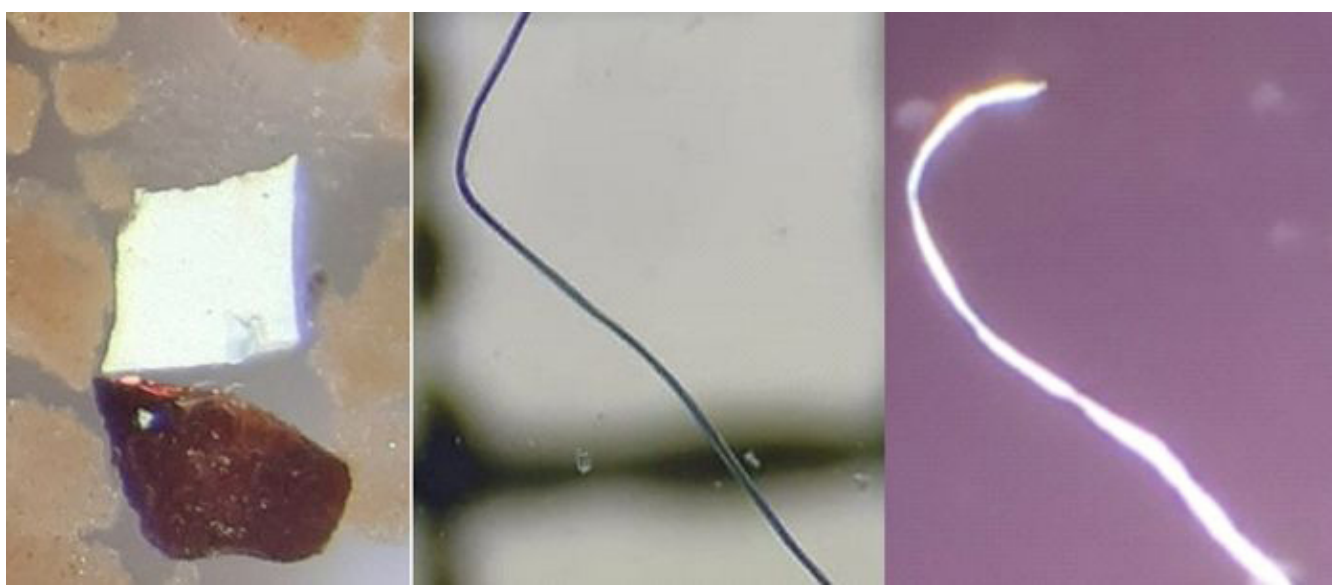

Figure 2. Microplastics found in stomach contents, left to right: white fragment under the microscope with direct light, blue fibre with direct light and the same fibre with polarized light showing birefringence behavior.

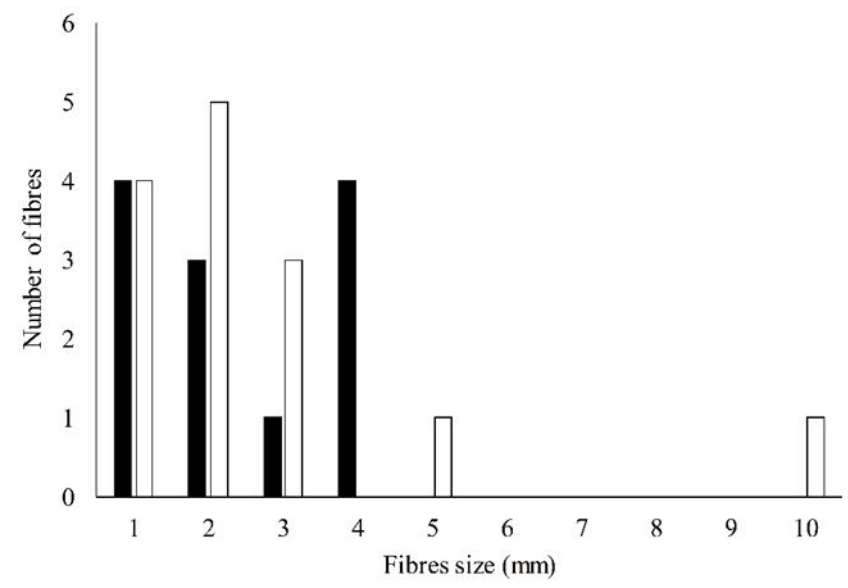

- Astyanax lacustris $\quad \square$ Iheringichthys labrosus

Figure 3. Fibre size frequency found in the gastrointestinal analyses of Astyanax lacustris and Iheringichthys labrosus. 
Table 1. The number of individuals $(\mathrm{n})$, standard length $(\mathrm{mm})$, and percentage of individuals with microplastics (MPs) of both analyzed species in Uruguay River, Brazil.

\begin{tabular}{|c|c|c|c|c|c|c|}
\hline \multirow{2}{*}{ Municipalities (Brazil) } & \multicolumn{3}{|c|}{ Astyanax lacustris } & \multicolumn{3}{|c|}{ Iheringichthys labrosus } \\
\hline & $\mathbf{n}$ & $(\mathrm{mm})$ & $\% M P s$ & $\mathbf{n}$ & $(\mathrm{mm})$ & \%MPs \\
\hline Alecrim & 6 & $111.5 \pm 30.1$ & 33.3 & 11 & $205.5 \pm 39.9$ & 27.3 \\
\hline Porto Vera Cruz & 11 & $120.7 \pm 16.3$ & 10.0 & 9 & $238.6 \pm 51.2$ & 33.3 \\
\hline São Borja & 13 & $132.4 \pm 21.7$ & 15.4 & 6 & $179.2 \pm 31.8$ & 33.3 \\
\hline São Paulo das Missões & 13 & $121.4 \pm 9.8$ & 38.4 & 2 & $241.0 \pm 21.1$ & 50.0 \\
\hline Roque Gonzales & 18 & $102.6 \pm 14.3$ & 16.7 & 1 & 101.0 & 100.0 \\
\hline
\end{tabular}

fragmented particles mix with natural food sources, where color and buoyancy can be confused with natural food (Boerger et al., 2010; Davison $\&$ Asch, 2011). Among the plastic fragments, microplastics are considered very aggressive to the environment, because they are polymers that adsorbed hydrophobic organic pollutants (e.g. PCBs, organochlorine pesticides, PAHs) and heavy metals (e.g. Lozoya et al., 2016; Rodríguez et al., 2020). In the Uruguay River, the contamination by microplastics, probably from water and sediments, is added to the already existing contamination among others, oils, heavy metals and pesticides. (e.g. Costa et al., 2016; Soutullo et al., 2020). These contaminants can be adsorbed to plastics increasing their potential toxicity. Thus, when the fishes consume the particle voluntarily or even aggregated with another food, they can promote various toxic effects, including endocrine disturbance, oxidative and metabolic stress, enzyme activity, and cell necrosis (Oliveira et al., 2013; Rochman et al., 2013; Mazurais et al., 2015). The consequences can compromise the survival, growth, and reproduction (Mazurais et al., 2015; Nobre et al., 2015).

This is the first record of an analysis of MPs in the gastrointestinal tract of fish of the Middle Uruguay river basin. There is still a great lack of information to be able to estimate the real impact of microplastic consumption by fish in the Uruguay River. For this aim, further studies have to be done assessing the magnitude and frequency of consumption, as well as the possible toxicity at individual level, that can we extended to population and community levels. In addition, it is important to take into account the relative importance of microplastics sources associated with different productive activities as well as the effects of urbanization.

Finally, the use of species widely distributed in the basin, with different feeding habits and occupying different strata in the water column and sediments may be important to make comparative studies related to plastic pollution. Because a differential distribution of microplastics in the water column and in the sediments is to be expected in relation to their density (positive or negative buoyancy). In this sense some siluriforms, such as I. labrosus could be good indicators of microplastics contamination in bottom sediments.

\section{Acknowledgements}

The authors T.S. and R.B. thank FAPERGS and CNPq for providing a scholarship, and Universidade Federal da Fronteira Sul (UFFS) for providing infrastructure. F.T.M., acknowledges the support of "Programa de Desarrollo de las Ciencias Básicas (PEDECIBA)" and "Agencia Nacional de Investigación e Innovación (ANII)”, Uruguay.

\section{References}

ABES, S.S., AGOSTINHO, A.A., OKADA, E. and GOMES, L.C. Diet of Iheringichthys labrosus (Pimelodidae, Siluriformes) in the Itaipu Reservoir, Paraná River, Brazil-Paraguay. Brazilian Archives of Biology and Technology, 2001, 44(1), 101-105. http:// dx.doi.org/10.1590/S1516-89132001000100014.

ANDRIAN, I.F., SILVA, H.B.R. and PERETTI, D. Dieta de Astyanax bimaculatus (Linnaeus, 1758) (Characiformes, Characidae), da área de influência do reservatório de Corumbá, Estado de Goiás, Brasil. Acta Scientiarum, 2001, 23(2), 435-444.

BOERGER, C.M., LATTIN, G.L., MOORE, S.L. and MOORE, C.J. Plastic ingestion by planktivorous fishes in the North Pacific Central Gyre. Marine Pollution Bulletin, 2010, 60(12), 2275-2278. http:// dx.doi.org/10.1016/j.marpolbul.2010.08.007. PMid:21067782.

BROWNE, M.A., CRUMP, P., NIVEN, S., TEUTEN, E., TONKIN, A., GALLOWAY, T. and THOMPSON, R. Accumulation of microplastic on shoreline worldwide: sources and sinks. Environmental Science \& Technology, 2011, 45(21), 9175-9179. http:// dx.doi.org/10.1021/es201811s. PMid:21894925.

COSTA, G.R., ROCHA, M.B., QUEROL, M.V.M., DAL MAGRO, J., MACHADO, M.M. and OLIVEIRA, L.F.S. Cd, $\mathrm{Cu}$, and $\mathrm{Mn}$ from Uruguay River Basin in Uruguaiana, RS, Brazil, and their toxicological potential for human leukocyte. Acta 
Scientiarum. Biological Sciences, 2016, 38(4), 439446. http://dx.doi.org/10.4025/actascibiolsci. v38i4.31998.

D'ANATro, A., VIDAL, N., GONZÁleZBERGONZONI, I., TEIXEIRA DE MELLO, F., TANA, J. and NAYA, D. Geographic and seasonal variation analysis of digestive morphology in the catfish Iheringichthys labrosus along lower Río Uruguay. Open Access Animal physiology, 2013, 5, 9-13. http://dx.doi.org/10.2147/OAAP.S47193.

DAVISON, P. and ASCH, R.G. Plastic ingestion by mesopelagic fishes in the North Pacific Subtropical Gyre. Marine Ecology Progress Series, 2011, 432, 173180. http://dx.doi.org/10.3354/meps09142.

EERKES-MEDRANO, D., THOMPSON, R.C. and ALDRIDGE, D.C. Microplastic in freshwater systems: a review of the emerging threats, identification of knowledge gaps and prioritization of research needs. Water Research, 2015, 75, 63-82. http://dx.doi.org/10.1016/j.watres.2015.02.012. PMid:25746963.

ESTEVES, K.E. Composição granulométrica do sedimento de um lago amazônico impactado por rejeito de bauxite e um lago natural (Pará, Brasil). Acta Scientiarum, 1996, 8, 115-126.

GOMIERO, L.M. and BRAGA, F. Length-weight relationship and condition factor for Cichla cf. ocellaris and Cichla monoculus (Perciformes, Cichlidae) in Volta Grande Reservoir, Rio Grande - MG/SP. Acta Scientiarum, 2003, 25, 79-86.

HARTZ, S.M., SILVEIRA, C.M. and BARBIERI, G. Feeding of Astyanax species Baird \& Girard, 1854 occurring in Lagoa Caconde, RS, Brazil (Teleostei, Characidae). Acta Scientiarum, 1996, 18(2), 269-281.

LACERDA, A.L.F., RODRIGUES, L.S., VAN SEBILLE, E., RODRIGUES, F.L., RIBEIRO, L., SECCHI, E.R., KESSLER, F. and PROIETTI, M.C. Plastics in sea surface waters around the Antartic Peninsula. Scientific Reports, 2019, 9(1), 3977. http://dx.doi.org/10.1038/s41598-01940311-4. PMid:30850657.

LOZOYA, J.P., TEIXEIRA DE MELLO, F., CARRIZO, D., WEINSTEIN, F., OLIVERA, Y., CEDRÉS, F., PEREIRA, M. and FOSSATI, M. Plastics and microplastics on recreational beaches in Punta del Este (Uruguay): unseen critical residents? Environmental Pollution, 2016, 218, 931-941. http://dx.doi.org/10.1016/j.envpol.2016.08.041. PMid:27554983.

MASDEU, M., TEIXEIRA DE MELLO, F., LOUREIRO, M. and ARIM, M. Feeding habits and morphometry of Iheringichthys labrosus (Lütken, 1874 ) in the Uruguay River (Uruguay). Neotropical Ichthyology, 2011, 9(3), 657-664. http://dx.doi. org/10.1590/S1679-62252011005000034.
MAZURAIS, D., ERNANDE, B., QUAZUGUEL, P., SEVERE, A., HUELVAN, C., MADEC, L., MOUCHEL, O., SOUDANT, P., ROBBENS, J., HUVET, A. and ZAMBONINO-INFANTE, J. Evaluation of the impact of polyethylene microbeads ingestion in European sea bass (Dicentrarchus labrax) larvae. Marine Environmental Research, 2015, 112(Pt A), 78-85. http://dx.doi.org/10.1016/j. marenvres.2015.09.009. PMid:26412109.

NOBRE, C.R., SANTANA, M.F.M., MALUF, A., CORTEZ, F.S., CESAR, A., PEREIRA, C.D.S. and TURRA, A. Assessment of microplastic toxicity to embryonic development of the sea urchin Lytechinus variegatus (Echinodermata: Echinoidea). Marine Pollution Bulletin, 2015, 92(1-2), 99-104. http:// dx.doi.org/10.1016/j.marpolbul.2014.12.050. PMid:25662316.

OLIVEIRA, M., RIBEIRO, A., HYLLAND, K. and GUILHERMINO, L. Single and combined effects of microplastics and pyrene on juveniles ( $0+$ group) of the common goby Pomatoschistus microps (Teleostei, Gobiidae). Ecological Indicators, 2013, 34, 641-647. http://dx.doi.org/10.1016/j.ecolind.2013.06.019.

ROCHMAN, C.M., HOH, E., KUROBE, T. and TEH, S.J. Ingested plastic transfers hazardous chemicals to fish and induces hepatic stress. Scientific Reports, 2013, 3(1), 3263. http://dx.doi.org/10.1038/ srep03263. PMid:24263561.

ROCHMAN, C.M., TAHIR, A., WILLIAMS, S.L., BAXA, D.V., LAM, R., MILLER, J.T., TEH, F.C., WERORILANGI, S. and TEH, S.J. Anthropogenic debris in seafood: plastic debris and fibers from textiles in fish and bivalves sold for human consumption. Scientific Reports, 2015, 5(1), 14340. http://dx.doi. org/10.1038/srep14340. PMid:26399762.

RODRÍGUEZ, C., FOSSATTI, M., CARRIZO, D., SÁNCHEZ-GARCÍA, L., TEIXEIRA DE MELLO, F., WEINSTEIN, F. and LOZOYA, J.P. Mesoplastics and large microplastics along a use gradient on the Uruguay Atlantic coast: types, sources, fates, and chemical loads. The Science of the Total Environment, 2020, 721, 137734. http://dx.doi.org/10.1016/j. scitotenv.2020.137734. PMid:32179346.

SIERRA, I., CHIALANZA, M.R., FACCIO, R., CARRIZO, D., FORNARO, L. and PÉREZPARADA, A. Identification of microplastics in wastewater samples by means of polarized light optical microscopy. Environmental Science and Pollution Research International, 2020, 27(7), 74097419. http://dx.doi.org/10.1007/s11356-01907011-y. PMid:31884541.

SILVA, Z., NASCIMENTO, P.E.C., VITULE, J.R.S., FREHSE, F.A., FERRAZ, M.S.O. and MOURGUÉS-SCHURTER, L. Dieta e compartilhamento de recursos por duas espécies de Pimelodidae em um reservatório do sudeste brasileiro. 
Biota Neotropica, 2019, 19(3), e20180675. http:// dx.doi.org/10.1590/1676-0611-bn-2018-0675.

SOUTUllO, A., RÍOS, M., ZALDÚA, N. and TEIXEIRA DE MELLO, F. Soybean expansion and the challenge of the coexistence of agribusiness with local production and conservation initiatives: pesticides in a Ramsar site in Uruguay. Environmental Conservation, 2020, 47(2), 97-103. http://dx.doi. org/10.1017/S0376892920000089.

VIDAL, N., TEIXEIRA DE MELLO, F., GONZÁLEZX BERGONZONI, I., LÓPEZ-RODRÍGUEZ, A., TESITORE, G., PAIS, J., STEBNIKI, S., SILVA, I. and D'ANATRO, A. Long冈term study of the reproductive timing of the Neotropical catfish Iheringichthys labrosus (Lütken, 1874): Influence of temperature and river discharge. Ecology Freshwater Fish, 2020, 29(2), 334-345. http://dx.doi. org/10.1111/eff.12518.
WOODALL, L.C., GWINNETT, C., PACKER, M., THOMPSON, R.C., ROBINSON, L.F. and PATERSON, G.L. Using a forensic science approach to minimize environmental contamination and to identify microfibres in marine sediments. Marine Pollution Bulletin, 2015, 95(1), 40-46. http:// dx.doi.org/10.1016/j.marpolbul.2015.04.044. PMid:25936572.

WU, C., ZHANG, K. and XIONG, X. Microplastic pollution in inland waters focusing on Asia. In: M. WAGNER and S. LAMBERT, eds. Freshwater microplastics: emerging environmental contaminants? Switzerland: Springer Open, 2020, pp. 101-124.

Received: 09 April 2020 Accepted: 14 August 2020

Associate Editor: Ronaldo Angelini. 